\title{
Malczewski, Jacek
}

Jacek Malczewski (1854-1929), a Polish nobleman, was a painter and illustrator, known as an outstanding representative of the Young Poland art movement around 1900 and European Art Nouveau (secession). An influential teacher as well, he is regarded as the "father" of Polish symbolism in painting in the early 1890s. Much of his oeuvre is saturated with biblical subjects, themes, and motifs.

As a pupil of, among other notable artists, the Polish historical painter Jan Matejko (see "Matejko, Jan”), Malczewski completely deviated from Matejko's style and national historical themes, preferring as a source of inspiration more universal cultural motifs - for example, the Bible, ancient mythology, music, customs, and folklore. He traveled to Italy $(1880,1890)$, Greece and Turkey (1884), Paris and Munich (1885-86, 1893), and Vienna (1914-16).

In his painting, Malczewski was inspired by Polish art (especially the Romantics - e.g., Artur Grottger [1837-1867]), Polish folk tradition (e.g., reflected in his series of fairytale paintings entitled The Rusalkas [Rusatki, 1887-88], of which the multiple pictures are in different museums in Poland, e.g., Regional Museum, Rzeszów, and Museum of the Jagiellonian University, Kraków, among others), and patriotic themes of Polish independence and regional folklore. His work also draws from mythological motifs (esp. Greek myth, as relating to chimeras, harps, jellyfish, fauns, tritons) and biblical themes. In his paintings, he included typical mythological topoi of the fin de siècle, present, e.g., in parallel with German symbolist painters such as Arnold Bocklin (1827-1901) and Max Klinger (18571920). The "iron" canon of Malczewski's most outstanding works includes Melancholy (Melancholia, 1890-94, National Museum [gallery in Rogalin], Poznan); Vicious Circle (Btędne koto, 1895-97, National Museum, Poznan); Poisoned Well (Zatruta studnia, 1905-06, National Museum, Poznan); another painting with that same title, Poisoned Well (1907, Lwowska Galeria Sztuki imienia Borysa Woźnickiego, Lwów/Lviv); and the Polonia cycle (1914-18), of which the paintings are found in various Polish museums, e.g., the National Museum of Kielce. Malczewski was awarded medals at international exhibitions in Berlin (1891), Munich (1892), and Paris (1900) for his works.

Malczewski, alongside Stanisław Wyspiański and Józef Mehoffer (other students of Matejko), was 
one of the most outstanding Polish artists of the socalled "Art around 1900" in Kraków. In his rich body of work he included many Christian religious motifs, not a few of them biblical, which he often combined in a single painting with a contemporary cultural context - e.g., by painting self-portraits or contemporary customs from his era (19th-20th cent.) together with symbolic scenes. He often painted a series of images, capturing one topic from different angles to address its various implications. His biblical images also have universal, parabolic, metaphorical, or allegorical dimensions, capturing diverse religious, ethical, historical, and contemporary aspects in a variety of representations. These included the apocalyptic scale of destruction in Poland during World War I, and other existential, metaphysical, and spiritual themes, as when the artist gives the biblical features to his own face: e.g., when the many faces of Jesus or the prophet Ezekiel are actually self-portraits of Malczewski.

Malczewski created images about strictly biblical themes (e.g., John the Baptist with Salome [Św. Jan Chrzciciel $z$ Salome, 1911], it was shown by the artist in the spirit of Catholic Modernism) as well as images that only indirectly suggest biblical topics. These might include biblical characters, symbolic objects, or customs derived from the Bible: e.g., angels; Tobias (from the Book of Tobit); Christmas (in connection with the Gospels); the three theological virtues of faith, hope, and love (taken from the Pauline letters); and apocalyptic scenes from the NT. Among Malczewski's "biblical” paintings (i.e., those inspired by biblical themes or containing metaphorical images related to biblical allusions or religious topics; and those which directly depict biblical scenes) are the following, listed here chronologically, by date of creation:

1) Maundy or The Washing of the Feet (Umywanie nóg, 1887, National Museum, Poznan)

2) Christmas Eve in Siberia (Wigilia na Syberii, 1892, National Museum Kraków)

3) Crucifixion (Ukrzyżowanie, 1898, Roman Catholic Church of St. Catherine of Alexandria [Parish Church], Olesno, Małopolska, Poland [this work was stolen in 1983])

4) Resurrection [Immortality] (Zmartwychwstanie [Nieśmiertelność], ca. 1900, National Museum, Poznan) $($ see $\rightarrow$ plate 7.a)

5) Angel, I will follow you (Aniele pójdę za tobạ, 1901, National Museum, Warsaw)

6) Faith, Hope, Love [triptych] (Wiara, nadzieja, mitość [tryptyk], 1901, National Museum, Poznan)

7) Behind the Angel [triptych] (Za aniotem [tryptyk], 1901, National Museum, Kraków)

8) Angel and Shepherd (Aniot $i$ pastuszek, 1903, National Museum, Wroclaw)

9) Tobias on the Road, or Tobias's Journey (Tobiasz w drodze, 1904, private collection)

10) Spring - Landscape with Tobias (Wiosna - Krajobraz $z$ Tobiaszem, 1904, National Museum, Poznan)
11) Three Angels with Tobias (Trzej Aniotowie $z$ Tobiaszem, or Trzy Anioty $z$ Tobiaszem, 1906, Lwowska Galeria Sztuki imienia Borysa Woźnickiego, Lwów/Lviv) a.k.a. Tobias with angels (Tobiasz $z$ aniotami)

12) Tobias with Angels (Tobiasz $z$ aniotami, ca. 1908 , Silesian Museum, Katowice) [not to be mistaken with the previous painting of similar title]

13) The Tribute Money (Grosz czynszowy, 1908, National Museum, Poznan)

14) Crucifixion (Ukrzyżowanie, 1904-08, Roman Catholic Church of All of the Saints (Parish Church), Bobowa, Małopolska, Poland

15) Christ in Emmaus (Chrystus $w$ Emaus, 1909, Lwowska Galeria Sztuki imienia Borysa Woźnickiego, Lwów/Lviv)

16) Adoration of the Madonna/Adoration of Our Lady (Adoracja Madonny, the central part of the triptych Go to the streams [Idź nad strumienie], 1910, National Museum Warsaw)

17) Christ before Pilate (Chrystus przed Pitatem, 1910, Lwowska Galeria Sztuki imienia Borysa Woźnickiego, Lwów/Lviv), depicting Pilate's judgment over Jesus

18) four separate versions of Christ and the Samaritan Woman [at the Well] (Chrystus $i$ Samarytanka [u studni]): one of 1909, Museum of the Archdiocese of Warsaw, Warsaw; one of 1910, private collection; one of 1911, private collection; and a second of 1911, Lwowska Galeria Sztuki imienia Borysa Woźnickiego, Lwów/Lviv

19) St. John the Baptist with Salome (S'w. Jan Chrzciciel $z$ Salome, 1911, National Museum, Poznan)

20) Doubting Thomas (Niewierny Tomasz, 1911, private collection)

21) Tobias and the Fates, or Tobias and the Parcae [or the Morai / Moirae] (Tobiasz i Parki, 1912, National Museum, Poznan)

22) Self-portrait with Archangel Raphael, Tobias, and the Morai [or Moirae] / Parcae] (Autoportret z Archaniotem Rafatem, Tobiaszem i Parkami, 1912, National Museum, Warsaw)

23) Ezekiel's prophecy [triptych] (Przepowiednia Ezechiela [tryptyk] (1918, private collection)

24) Prophecy of Ezekiel (Proroctwo Ezechiela (1919, Museum of Art, Łódź)

25) Crucified (Ukrzyżowany, without year, probably after 1919, before 1929, Diocese Museum, Tarnów)

Certain works by Malczewski display the biblical symbolism of the road, featuring the motif of homo viator (man, the traveler or wayfarer), rooted in Ps 27/28:13, 1 Pet 2:11, and Heb 11:13. This symbolism occurs, e.g., in a series of paintings illustrating the travels of Tobias (or Tobit) and his identically-named son Tobias (from the Book of Tobit): Tobias on the road, Angels with Tobias, and the surrealist picture, Spring Landscape with Tobias, which shows 
the younger Tobias carrying a healing fish for his father. Malczewski combined biblical motifs of Tobias' wandering with the mythological, ancient Greek motif of death (Thanatos) in the painting Tobias and Fates. Malczewski's biblical materials also include the angelological motif of a shepherd meeting his guardian angel, who is his guide on the journey (in the series of paintings: Angel, I will follow you, Angel and Shepherd, and the triptychs Faith, Hope, Love and Behind the angel; etc.

Malczewski lost his sight at the end of his life, which caused him to stop painting. In 1928 he was elected a member of the Czech Academy of Sciences and Arts (Česká akademie věd a umění in Prague, then known as Czechoslovakia).

Bibliography: - Bodziachowska, K. M., Jacek Malczewski: Zaklęty u źródta ... [Jacek Malczewski: the enchanted at source] (Warsaw 2017). - Kossowska, I., "Jacek Malczewski” (Institute of Art, Polish Academy of Sciences; Warsaw 2002) [available at https://culture.pl]. - Kudelska, D., Dukt Pisma $i$ pecdzla [The duct of scripture and brush] (Lublin 2008). - Ławniczakowa, A., Jacek Malczewski: Katalogwystawy monograficznej [Jacek Malczewski: catalog of the monographic exhibition] (National Museum in Poznan; Poznan 1968). - Puciata-Pawłowska, J., Jacek Malczewski (Wrocław 1968). - Pulnar-Ferdjani, I./P. Szymalak, Jacek Malczewski: znany i nieznany [Jacek Malczewski: known and unknown (Jacek Malczewski Museum; Radom 2013). - Stopyra, M., Jacek Malczewski w obrazach mniej znanych [Jacek Malczewski in lesserknown paintings] (Rzeszow 2007). - Tytko, M. M., Jacka Malczewskiego lekcja anatomii [Jacek Malczewski: anatomy lesson], in Scientific and Artistic Books of the Faculty of Painting of the Academy of Fine Arts in Krakow (Kraków 2004) 233-40.

Marek Mariusz Tytko 